\title{
CONTRIBUTIONS TO THE BIOLOGY OF THE MACKEREL, SCOMBER SCOMBRUS L.: MACKEREL MIGRATIONS IN THE ENGLISH CHANNEL AND CELTIC SEA
}

\author{
By G. A. Steven, B.Sc., F.R.S.E. \\ Zoologist at the Plymouth Laboratory
}

(Text-figs. I-6)

\section{INTRODUCTION}

The common mackerel (Scomber scombrus L.) is one of the important European food fishes. Forty-two species of commercial sea fishes are listed by the Conseil Permanent International pour l'Exploration de la Mer in its Bulletin Statistique des Pêches Maritimes as being landed in northern and western Europe. Four-fifths of these landings are made up of only twelve important food fishes, of which the mackerel is one. In 1937 (Thompson, I939), the last year for which full normal figures are available, ${ }^{1}$ approximately $\mathrm{I}_{4}^{1}$ million cwt. of mackerel were landed by all the countries of northern and western Europe (excluding Russia), having a total value, as nearly as can be ascertained, of just over $£ 887,000$. To this total Great Britain, Eire, and Northern Ireland contributed rather more than $14 \%$ of the quantity and almost $13 \%$ of the value. During the inter-war period, however, Britain's contribution had fallen steadily, her share in I913 (a year that has long been used as a standard of comparison) being no less than $49 \%$ of the total quantity and 3r \% of the total value of all mackerel landings.

Of the British Islands, England is the chief mackerel-fishing country. Just prior to the outbreak of the recent war her total landings were some I40,000 cwt. valued at about $£ 80,000$. It is a noteworthy fact that rather more than one-third of this quantity was landed at the single small port of Newlyn, in Cornwall (Figs. I and 2). It is still more surprising to note (Fig. I) that during the four years 1923-1926 more mackerel were landed at Newlyn than at all other ports in England and Wales put together.

There are, in normal times, two distinct mackerel fisheries worked from Newlyn. One is a long-distance, deep-sea fishery carried out by steam drifters (of the normal herring drifter type) in the Celtic Sea far to the westward of the Scilly Islands-except towards the end of the season when fishing takes place nearer land. This fishery will be called the Newlyn Deep-Sea Fishery for

1 The figures for 1938, though published in 1944, are not complete. 
mackerel. The other is an inshore fishery that takes place in inshore waters off the northern coasts of the Cornwall and Devon peninsula. In it, boats from other small ports take some part, but Newlyn is the chief centre. This fishery will therefore be called the Newlyn Inshore Fishery for mackerel.

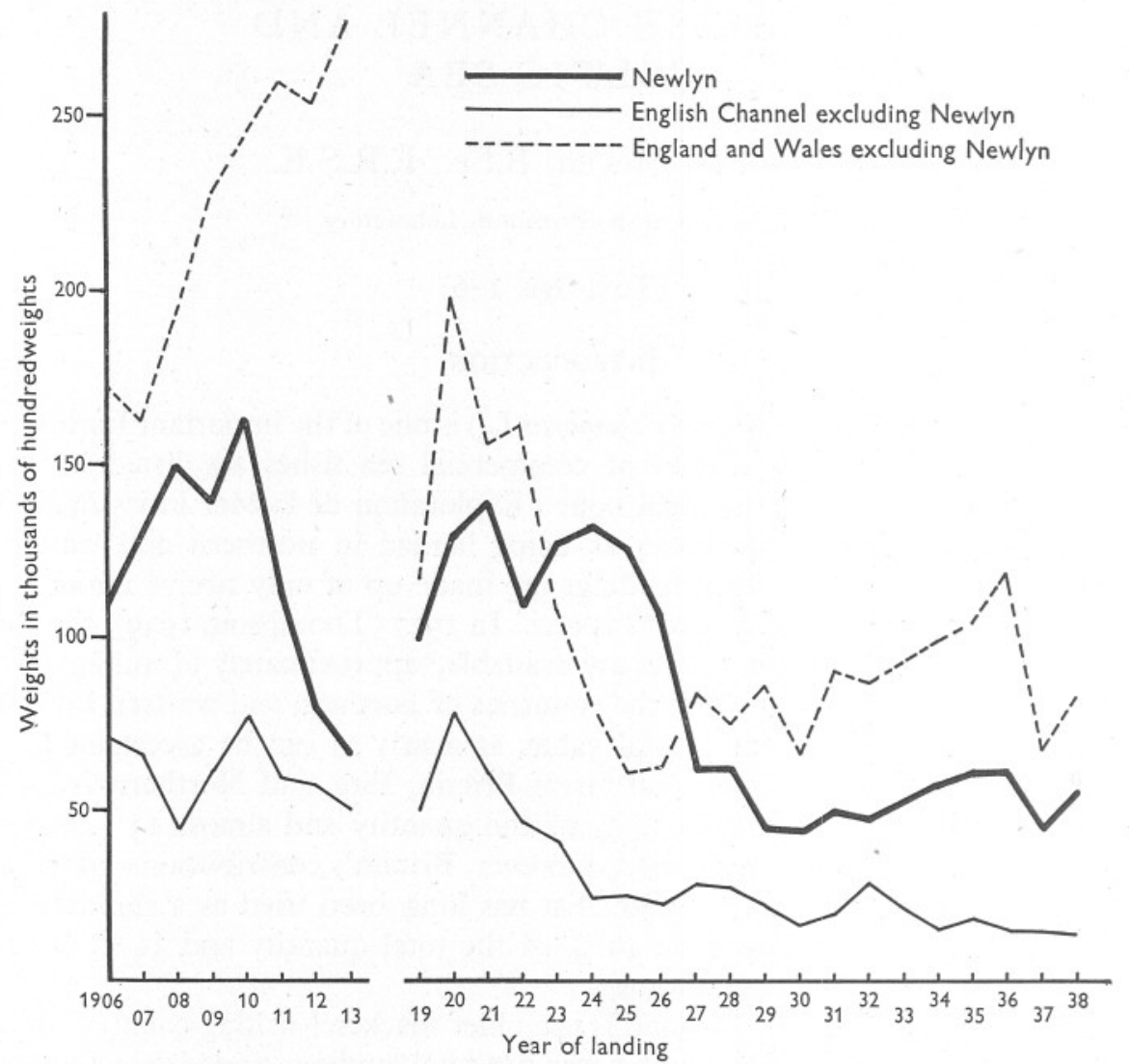

Fig. I. Mackerel landings in thousands of hundredweights at Newlyn (-); in England and Wales excluding Newlyn (----); and at English Channel ports excluding Newlyn $(-)$. From Sea Fisheries Statistical Tables for the years 1906-1938 inclusive.

At Newlyn, then, in normal times, by far the most important mackerel fishery in Great Britain takes place, and it was at this port that most of the data for this investigation were collected.

The Newlyn mackerel fisheries were temporarily suspended during the I9I4-I8 war and again in the Second World War. Unfortunately, normal fishing has not yet been resumed after this second interruption owing to the uneconomic prices obtainable for mackerel in comparison with operating costs.

In past years there was also a flourishing mackerel fishery farther up the English Channel at Plymouth; but the Plymouth fishery, for purely economic 
reasons, gradually declined and came entirely to an end about the year 1926. This fishery will be called the Plymouth Channel Fishery for mackerel. A brief but detailed description of all these fisheries will now be given because an adequate knowledge of them is necessary for obtaining a clear picture of the migratory movements of the mackerel upon which they all depend.
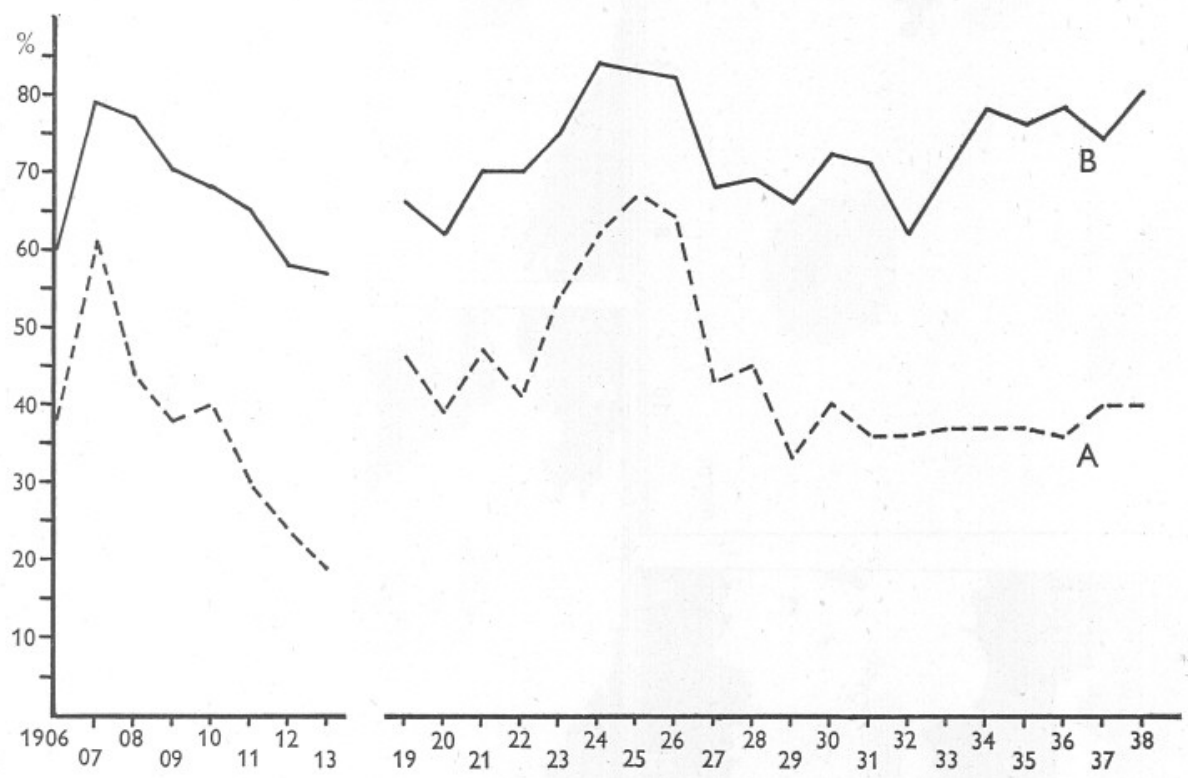

Fig. 2. Percentage contribution by Newlyn to total landings $(A)$ in England and Wales; $(B)$ at English Channel ports, from 1906 to 1938 inclusive.

\section{The Plymouth Channel Fishery}

Although this fishery no longer exists, it is necessary to examine its previous activities in considerable detail, for mackerel are still present on the grounds worked by it long ago and the same migrations still take place by fish that are now untouched by any catching instrument.

The mackerel season began off Plymouth towards the end of December or early in January and boats from east and west used to converge on the port in large numbers to take part in it. Ridge ( 1889, p. 72$)$, reporting on the fishery of 1888 , states that fishing began in that year in January and that vessels from Yarmouth, Lowestoft, Newhaven, Brighton, Eastbourne, Hastings, Porthleven, Newlyn, and Mousehole arrived to take part in it. According to Calderwood, (I892, p. 279) the Plymouth drift-net fleet alone at this season used to number between three and four hundred sail.

In a series of reports on fishing in the neighbourhood of Plymouth, in different months of each year towards the close of last century (I892 and I893), 


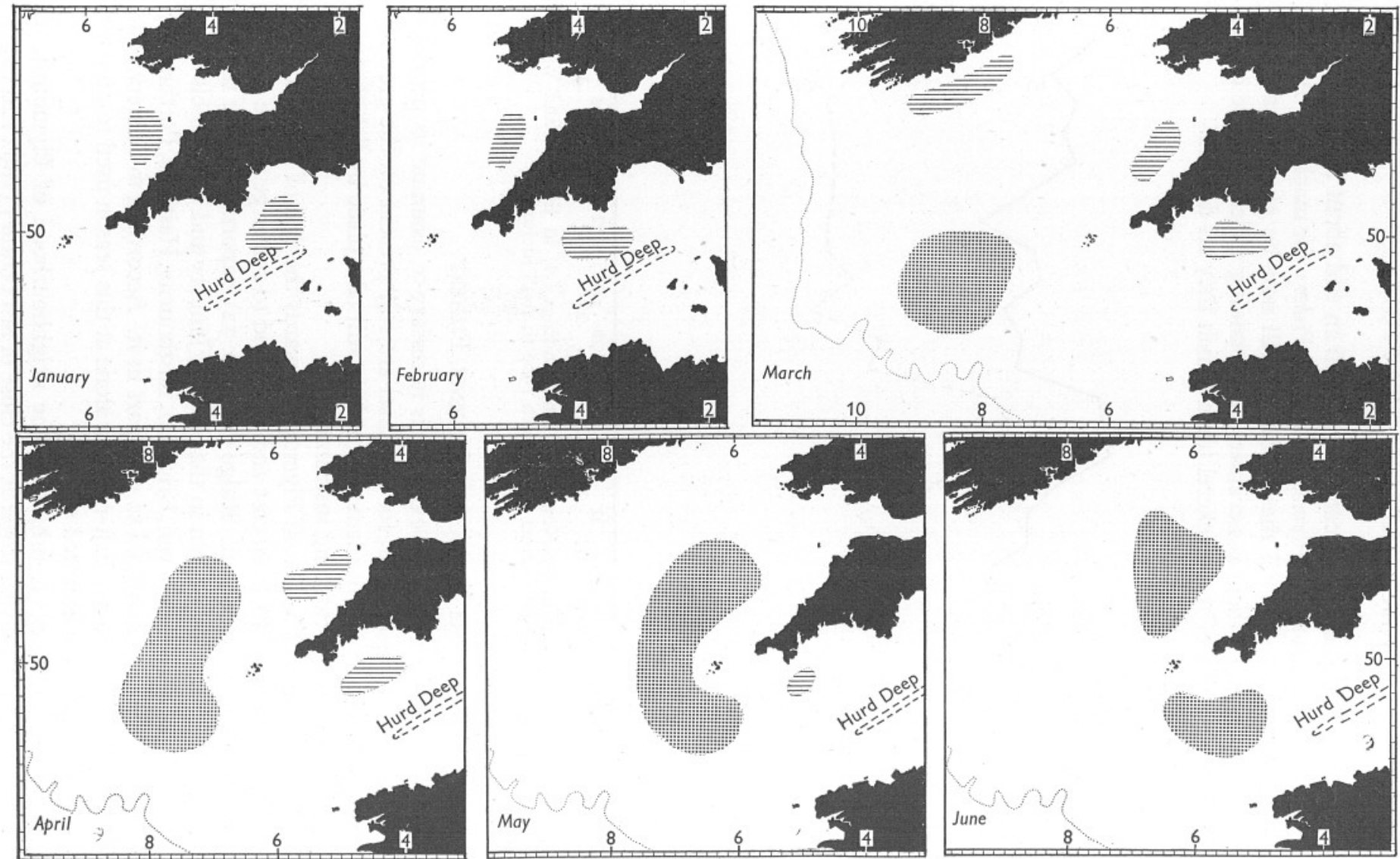

Fig. 3. Generalized charts showing times of fishing for mackerel in different parts of the English Channel and Celtic Sea.

Hatched areas, inshore fisheries; stippled areas, deep-sea fishery (vide pp. 519-24). The Ioo-fathom contour is indicated by a dotted line. 
Calderwood constructed a series of monthly charts showing as nearly as possible the kinds of fish caught during each month and the positions of the grounds being worked. From these reports, and from conversations with some of the old fishermen who were active at that time, one finds that in January fishing for mackerel took place on grounds to the eastward of Plymouth, generally from Io to 30 miles south to south-west of Start Point. As the season advanced the fish had to be sought progressively farther and farther to the westward. By the middle or end of March the fleet would be working from to to 30 miles southward from the Eddystone lighthouse (i.e. 20-40 miles to the seaward of Plymouth). By May the best catches were generally to be had on grounds still farther west, and the Plymouth fleet sometimes went as far as 40 miles southwest of Lizard Head before terminating the season's fishery. The time at which this occurred varied from year to year, but was seldom if ever later than the middle or end of May. When this happened many of the east coast boats returned to their home ports to fish no more for mackerel until another 'westcountry season' came round. But some of them, together with the westcountry boats, proceeded to Newlyn and other Cornish ports to carry on fishing from there on the deep-sea grounds to the westward of the Scilly Islands (vide p. 522). This sequence of events in the Plymouth fishery is summarized in Fig. 3 in which the hatched area in the English Channel indicates the extent of the fishing ground and the gradual shift of the fishery from its eastern end in January to its western extremity in May.

It should be noted that these west-going shoaling fish never approach really close to the land, but always remain at some distance from it. This is in marked contrast to what happens when mackerel reappear in the Channel in June after the shoals have broken up (vide p. 524). The fish then appear hard by the beaches and in creeks and harbours all along the shoreline in the very shallowest water.

\section{The Newlyn InSHore Fishery}

This fishery is confined to inshore grounds along the north Cornwall and north Devon coast. On these grounds, extending roughly from 20 to 50 miles northnorth-east of the Longships Lighthouse (Land's End), fishing in normal times begins in December or early January and continues for 3 or 4 months. At the beginning of its season the best catches are to be expected well to the northward and then progressively farther southward as the season advances. The hatched area to the north of the Cornwall-Devon peninsula in Fig. 3 indicates the extent of this fishing ground and the gradual shift of the fishery from its northern end in January to its south-western extremity by about April.

The sequence of events in this area should be carefully compared with that on the fishing grounds in the English Channel (also shown on this chart and already described) and their similarity noted. 


\section{The Newlyn Deep-Sea Fishery}

The modern great spring mackerel fishery from Newlyn opens in March (Fig. 3) on grounds right out in the open Atlantic far to the westward of the Scilly Islands. It is a drift fishery carried on by steam drifters of the familiar herring-drifter type which come to this port from the east coast ports of Yarmouth and Lowestoft.

Although fishing begins in the first days of the month, it is usually somewhere about the middle of March before the fleet falls in with the main shoals. While the search for them is going on, some of the boats try their luck hard by the Irish coast to the south-west and south of Ireland. From Io to 20 miles south to south-west of Fastnet Rock and about the same distance off Galley Head and the Old Head of Kinsale are the most favoured localities; and good catches are sometimes made there, but for only a very short time at the beginning of the season (Figs. 3 and $4 \mathrm{~A}$ ).

The charts in Fig. 4 have been prepared to show the locus of this fishery as indicated by the activities of ten drifters out of a total fleet of twenty-four in I938-a typical year. The information upon which the charts are based was derived from log-book records kept by each vessel. Every shot made by each of the ten drifters throughout the season is indicated by a dot in the position in which it was made. The fishing of these ten vessels is fully representative of that of the total fleet and gives a true picture of the changes in the locus of the fishery as the season advanced.

It will be seen (Fig. $4 \mathrm{~A}$ ) that during the first fortnight of March-the opening fortnight-there was only limited fishing, concentrated chiefly near the south coast of Eire. A few exploratory tries were also made over a widely scattered area to the westward of the Scilly Islands. This 'scatter' indicates the absence of good fishing in that locality as yet. By the second half of March (Fig. 4 B) fishing is in full swing with the area of chief fishing intensity located from 70 to Ioo miles west to west-south-west of the Bishop Rock, Isles of Scilly. During the first half of April (Fig. 4 C) the best fishing still persists in approximately the same place but slightly less distant. A few tries were also made on northern grounds about 70 miles north-north-west of the Longships (Land's End), but failed to find many fish. By the second half of April (Fig. 4 D) the locus of chief fishing intensity had moved to these northern grounds, all the vessels having for the time being forsaken the 'southern' grounds. During the first half of May (Fig. 4 E) good catches were being taken to the westward of Scilly, but considerably closer to land (i.e. farther to the eastward) and on a slightly more southerly bearing. After the middle of the month (Fig. $4 \mathrm{~F}$ ) most fish were encountered still farther in towards the mouth of the English Channel, and, being productive of good catches, attracted most of the fleet to this locality. During the first half of June (Fig. $4 \mathrm{G}$ ) fish were being caught both to the northward of Scilly and southward from Mounts Bay, the northern 

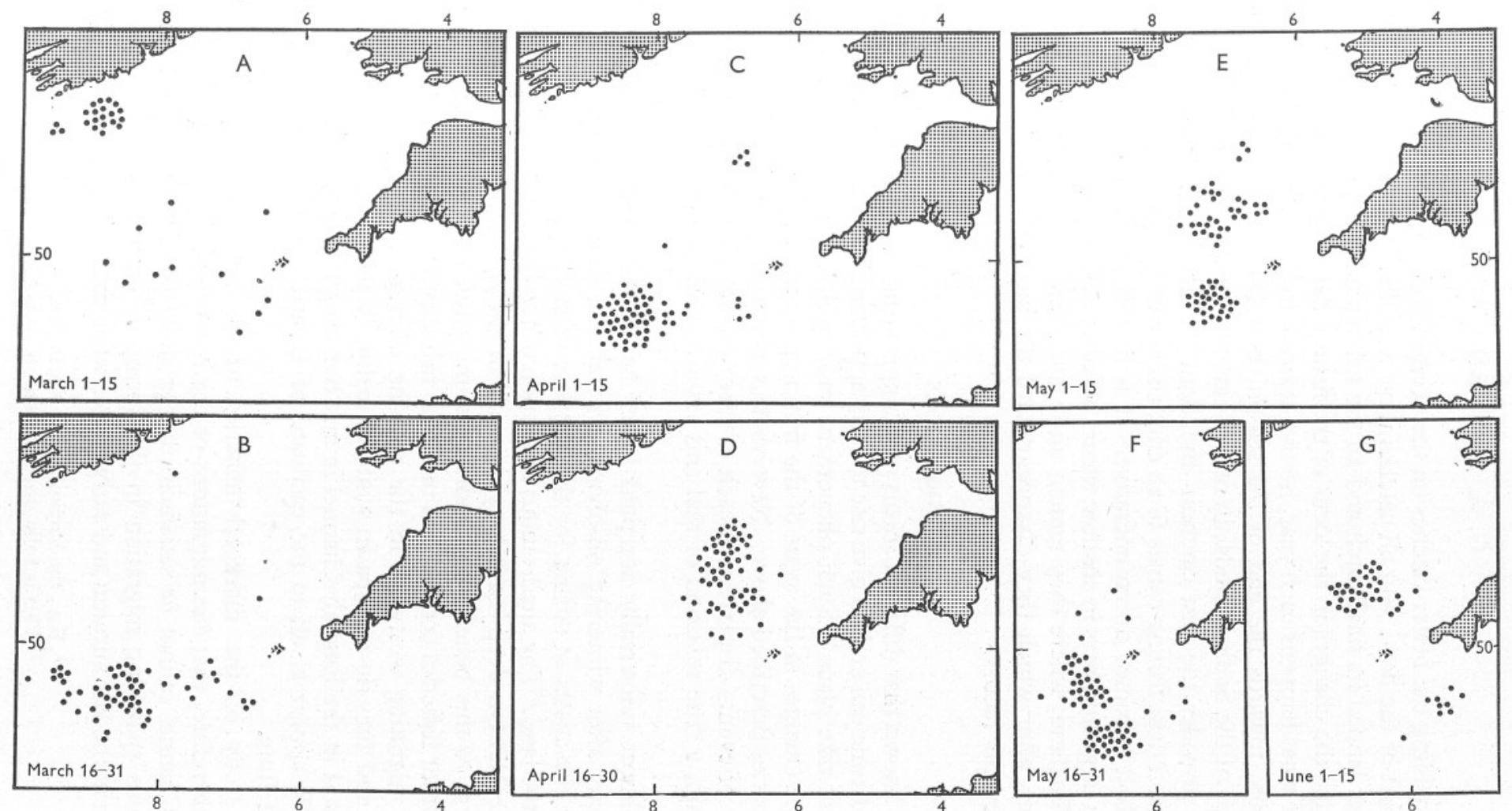

Fig. 4. Locus of mackerel fishing in 1938 by Newlyn-based steam drifters; A, in the first half of March; B, in the second half of March; C, in the first half of April; D, in the second half of April; E, in the first half of May; F, in the second half of May; G, in the first half of June. Each dot represents a 'shot' by one of ten selected drifters. 
locality yielding the better catches on the average and therefore attracting the greater part of the fleet. But all catches were now dwindling; on I5 June the last drifter landed its final catch and all the fishing stopped.

Although the changes in the locus of the fishery depicted in Fig. 4 A-G are typical of what happens each year, no two seasons are ever quite the same. In some years, towards the end of the season, best fishing is obtained to the northward of the Scilly Islands; in other years the western end of the English Channel provides the best catches. By about the middle or end of June in every season drift fishing comes to an end, the shoals having so dispersed that this method becomes unremunerative. It is at this time that the mackerel appear in large numbers in shallow waters all along the shores of southern and western England, where they remain until late September, October, or even November, after which they disappear until the next year when the whole cycle of events recurs.

\section{Migrations}

It is well known that different shoals of fish appearing in orderly succession in space and time can and do give rise to false appearances of migrations that do not in fact take place. ${ }^{1}$ Such phenomena may well underlie, to some slight extent, the changes in the locus of the fishing grounds shown by each of the three fisheries described above. Nevertheless, there can be no doubt that the sequence of events displayed by each of them during its respective season is, in the main, a true reflexion of real and extensive migrations by large bodies of fish.

The almost universally accepted belief has always been that mackerel everywhere, after wintering off-shore, generally in some unknown locality, approach the coasts in spring for the purpose of spawning in shallow water close by the land. ${ }^{2}$ The anadromous migration of the large shoals of fish upon which the Newlyn deep-sea fishery depends might appear at first sight fully to conform to this belief; the catadromous migrations of those that support the two other fisheries certainly do not. The fish that are found in the English Channel migrating westward in the opening months of the year disappear offshore, and they do not spawn while in inshore waters. Mackerel eggs are never found in the English Channel in any but insignificantly small numbers and hardly appear at all to the eastward of Lizard Head before about the middle of June.

Close study of the mackerel fisheries in the south-west of England reveals, therefore, that the migrations of the mackerel in the Celtic Sea and English Channel cannot be satisfactorily explained simply by postulating an anadromous spawning migration in the spring of each year and a reverse migration in the late autumn and early winter when mackerel largely disappear

1 E.g., the herring in the North Sea.

2 This is fully discussed on pp. 532-4. 
from inshore surface waters. Still less will this explanation suffice in the light of the knowledge we now possess that in all this wide region there is only one important spawning ground lying far out to the westward of the English coast. This spawning ground has been surveyed in detail and the results described elsewhere by Steven \& Corbin (1939) and more fully by Corbin (1947). From the information contained in those papers a generalized diagram has been

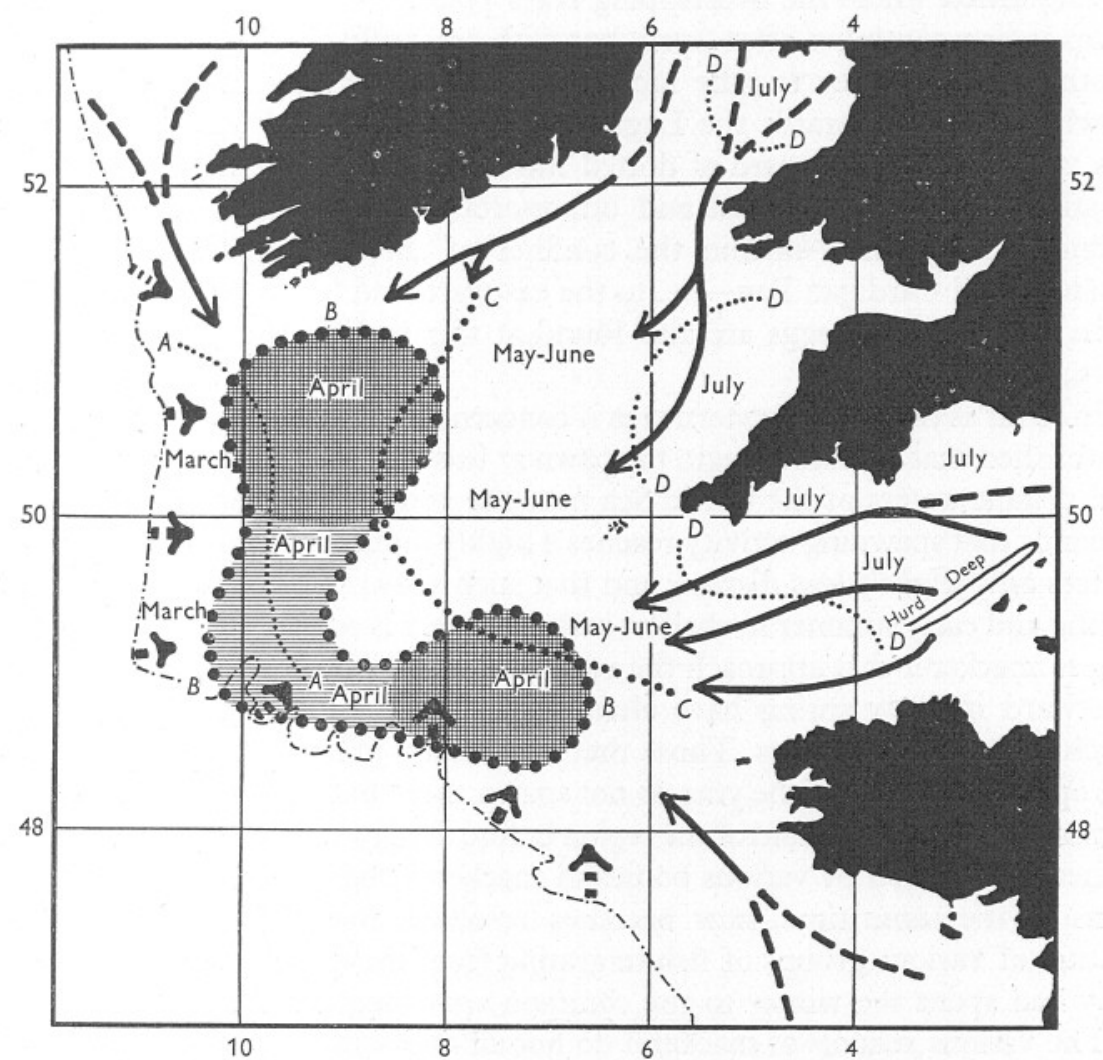

Fig. 5. Generalized diagram indicating the migrations of the mackerel in the English Channel and Celtic Sea in relation to the spawning ground. For further explanation see text, pp. 525-6. $\cdot \cdot \cdot \cdot \cdot \cdot \cdot=$ I00-fathom contour.

prepared (Fig. 5), from which can be seen at a glance the location of this spawning ground and its relation in space to the mackerel movements revealed by the three commercial fisheries described above.

Spawning on a small scale begins as early as March to the westward of the dotted line $A$ in Fig. 5-i.e. in the vicinity of the Ioo-fathom contour which, in that area, closely follows the outer edge of the great continental plateau lying to the south of Ireland. The greatest intensity of spawning takes place in April in the area enclosed by the dotted line $B$. Within this area there are 
two sub-areas (darkly stippled in Fig. 5) of maximum egg density-one situated from 40 to Ioo miles south of Fastnet, and the other from 50 to 80 miles south-west of the Scilly Islands. It will be seen that these two subareas are situated opposite and to seaward of the entrances to the Irish Sea and the English Channel. It may. well be that they represent two distinct spawning grounds that meet and overlap, and whose boundaries cannot be distinguished where the overlapping takes place.

Spawning continues after April, but with gradually decreasing intensity, for another 3 months or so, the locus of spawning activity moving the while slowly eastwards towards the English coast. In May and June all spawning has ceased to the westward of dotted line $C$. By July such meagre spawning as still continues is residual and unimportant and is confined to the close vicinity of the land-within the confines of the English Channel, Bristol Channel and Cardigan Bay-i.e. to the eastward and landward of dotted lines $D$ in Fig. 5. A few eggs are also found at this time in the Irish Sea (Scott, I9I3, I9I $4 a, b$ ).

In so far as the south-western area is concerned, therefore, it is now definitely established that mackerel begin to spawn at least as early as March in the deep and distant waters of the Celtic Sea near the roo-fathom line to the south of Ireland; that spawning activity reaches a highly intensive maximum in April in waters only slightly less distant; and that such spawning as continues into late spring and early summer in shallow inshore waters is residual and unimportant. Those mackerel that approach the south-western shores of England from the westward in early spring have already got rid of most of their eggs before reaching inshore localities. Those that are already present in coastal waters in the opening months of the year do not spawn there but migrate offshore to the common spawning ground of the region before doing so. The apparent anomaly hitherto presented by various bodies of mackerel migrating in different directions at the same time, now becomes resolved, therefore, into the simple picture of various groups of fish migrating from the different places in which they had spent the winter to the common spawning ground of the region.

The various schools of mackerel do not all arrive in the spawning region at the same time. This gives rise to the decided 'spread' of spawning activity in both space and time. Another contributory factor is that in this species the eggs mature in successive batches that are spawned one after another during an extended spawning period. Ripe translucent ova appear in the ovary distributed widely and irregularly amongst the still unripe yellowish ova, producing a peculiar, speckled appearance that for lack of a better term has been called the 'plum pudding' stage. These ripe ova are dehisced into the lumen of the ovary which then, on superficial examination, may show no trace of ripe eggs. Unless opened up such an ovary can be, and often has been, described as 'unripe'. In the mackerel, in fact, a fully ripe ovary is never present; the most that is ever found is an ovary containing some ripe eggs. Cunningham (I889, 
p. 25) was therefore in error in thinking that the ovaries and testes of all adult mackerel ripen rapidly and simultaneously and that 'all the reproductive products in a given fish are matured and shed within a short space of time'.

The important question now arises, where do the mackerel come from to this Celtic Sea spawning ground? It seems clear that many, perhaps even the majority, must have been in offshore waters prior to March, since we now know that some of them are already spawning at that time in the vicinity of the Ioo-fathom line (Fig. 5). Although definite proof is at present still lacking, there is good reason to believe that these fish had come out into deep water during the autumn of the previous year, at the time when they are known to disappear from the surface waters inshore. But where did they spend the ensuing winter? Before providing an answer it is convenient to consider first those other fish which, unlike the majority, do not move outward and westward into deep water in the autumn but spend the winter months on or near the sea bottom in shallower places nearer land-e.g. along the edge of the Hurd Deep some 40 miles south-east to south-south-west of Start Point (Cligny, I905, I912; Bullen, I908), along the southern side of the Vergoyer Bank near Boulogne, and around the numerous small scattered sand banks in the vicinity of Dieppe (Cligny, I905; Le Gall, I935). Of the northern fish, numbers sojourn during the winter months on the bottom around the Smalls and Saltees, and are fished from there, particularly by French trawlers (Le Gall, I928, I935). At this time these fish are truly demersal and can be caught on the sea floor by commercial trawlers specially equipped for the purpose.

It is not clear what the conditions are that attract the mackerel to certain restricted situations on the sea bed in winter. The only feature that can be detected as common to all of them is an interruption in the level of the sea bed caused by banks or gulleys. There is no uniformity of depth and none of temperature. Mackerel fished along the edge of the Hurd Deep are taken in about 40 fathoms; around the Vergoyer Bank in I2-I8 fathoms; in II-I4 fathoms around the Dieppe Banks; and in 30-50 fathoms in the Smalls and Saltees areas. It seems likely that associated with these unevennesses in the sea bed there must be some condition of turbulence-slight perhaps-that is all-important for the mackerel. Although the presence of well-defined mackerel shoals (such as those of the Hurd Deep, Vergoyer Bank and the other localities mentioned) cannot be recorded with absolute precision around the many declivities and acclivities on the floor of the Celtic Sea, mackerel are regularly trawled from various parts of it.

The winter habits of the mackerel, therefore, are now seen to fall into one coherent pattern and the inconsistencies that puzzled earlier writers arose simply through inadequate knowledge. The general statement that the mackerel is a pelagic and migratory fish must be modified. The adult mackerel, at any rate in the English Channel and Celtic Sea, is pelagic and migratory only during a portion of the year. In the other part it is demersal. During the first 
portion of its demersal period it packs densely in restricted areas and is nonmigratory. This was first noted by Cligny (1905, p. 99), who states that these bottom shoals are so dense and so sharply delimited that of two trawlers working side by side one will have a large catch of mackerel and the other none. This is also referred to by Bullen (I908, p. 283), and has been confirmed by old fishermen who participated in some commercially unsuccessful trawling experiments for mackerel from Plymouth.

The fortunes of the fishery reveal that this strongly delimited, densely packed phase of the bottom-living period lasts only for a short time-2 or 3 months at the most. Thereafter the concentration spreads outward in one or more directions from its focal point. In so doing the fish still remain in packs, but of more normal density, the extreme compactness of the first bottom phase having been lost. The Hurd Deep fish, for example, after remaining stationary in a restricted area along its edge until about January, then spread in a northwesterly direction towards Start Point and the Eddystone, where they are caught by French trawlers until the month of March or April.

During the years 1936-39 the Plymouth Laboratory's research ship Salpa and a local steam trawler caught 753 mackerel in nine small lots during January-April in an ordinary otter trawl towed very fast on the bottom in the Lizard-Start Point area. The positions of capture (shown as a composite diagram in Fig. 6) of even those few catches indicate a westerly spread of the fish on the sea floor in those early months of the year.

It is during this slow dispersal phase that the change-over from demersal to pelagic habit takes place. Not all at once, but successively, shoal after shoal rises to the surface, and, after they have done so, the spring migration to the spawning ground takes place.

The presence of the Plymouth drift fishery for mackerel off Start Point and the Eddystone in the early months of the year is thus easily understood. The fish that spend the earlier winter months in the vicinity of the Hurd Deep come to the surface in that area and then make their way 'down channel' on a spawning migration to the spawning grounds in the Celtic Sea. Likewise, the fish that winter by the Smalls spread southward across the mouth of the Bristol Channel before rising and continuing their way for some distance parallel to the Cornwall coast and then turn westward to the spawning grounds. On these fish the mackerel drift fishery of the North Cornwall coast in early spring depends. The Saltees fish, and perhaps others that have wintered to the westward of the St George's Channel, spread westward parallel to the Irish coast before rising and turning southward towards the spawning grounds, thus providing the catches close to the Irish coast in the early months of the year (vide p. 522).

It seems unlikely that all of the vast mackerel population of the whole south-western area can find room to winter hard by the slopes of the Hurd Deep and the various banks and shoals that have been mentioned. Doubtless 
some are present also in other inshore places (vide Green, I894, pp. 357-8); but even so, it seems certain that the vast majority must go farther afield to find similarly suitable conditions. This involves a return to the bottom of the Celtic Sea with its numerous banks and knolls, and it is significant that mackerel are regularly caught by British steam trawlers in their vicinity. It may well be that even those slopes also are not sufficient in number and extent

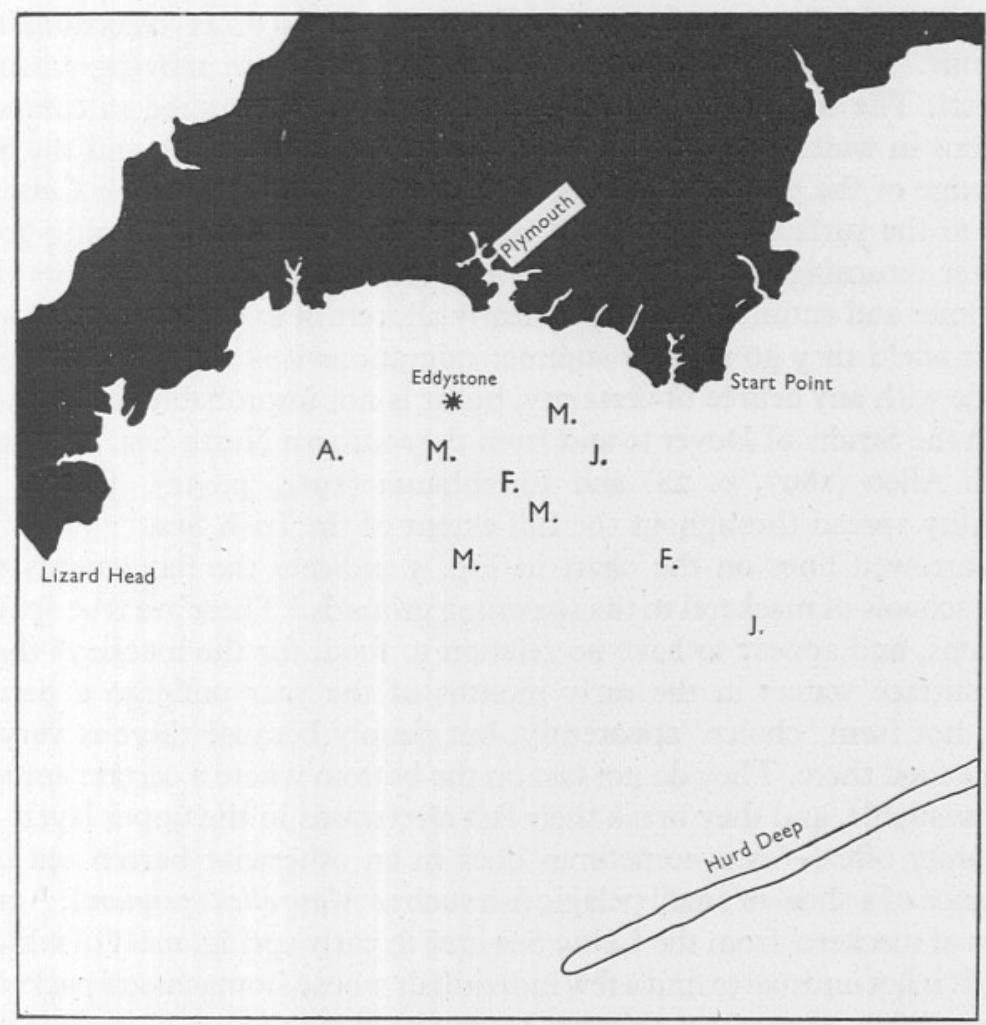

Fig. 6. Chart of area Start Point to Lizard Head. Letters indicate positions in which mackerel were captured on the bottom by two Plymouth vessels during the years I937-39. $\mathrm{J}=$ January; $\mathrm{F}=$ February; $\mathrm{M}=$ March; $\mathrm{A}=$ April.

to accommodate the whole population and that many fish have to seek the declivity of the continental slope in order to pass the winter in the conditions they require. That mackerel should spend the winter months hard by the outer edge of the continental plateau is entirely consistent with their known habit elsewhere of concentrating where there is an interruption in the level of the sea bed.

Although absolute proof is lacking, it appears to be a fully justifiable assumption that these mackerel, acting in conformity with what is now known 
of their fellows, spread inwards over the outer fringes of the continental plateau in the opening months of the year and then, rising from the sea floor, form part of the great pelagic shoals that migrate eastwards in the Celtic Sea and spawn there in the early spring before continuing their landward journey. In other words, that part of the sea floor from which they approach the spawning ground happens to be to the westward and seaward of it. Other fish, that wintered near other suitable acclivities and declivities nearer the coastlines, approach the spawning grounds from various other directions at the same time. But the directions in which the shoals are moving are merely incidental. The significant point is that they all have wintered in comparable conditions in widely scattered localities, from the Hurd Deep and the Smalls to the edge of the continental slope at the outer boundary of the Celtic Sea; all rise to the surface in spring and migrate to a common spawning ground, thereafter returning shorewards again and dispersing along the coasts during the summer and autumn; and all, or nearly all, return to the sea floor in winter. How far afield they go in their summer migrations it is at present impossible to decide with any degree of certainty, but it is not improbable that some pass through the Straits of Dover to and from the southern North Sea, as suggested by both Allen (1897, p. 28) and Ehrenbaum (19I4, p. 5I). Others in all probability spread throughout the full extent of the Irish Sea.

The arrowed lines on the chart in Fig. 5 indicate the movements of the various schools of mackerel to the spawning grounds. ${ }^{1}$ These are true spawning migrations, and appear to have no relation to food, for the mackerel that rise to the surface waters in the early months of the year undergo a period of fasting, not from 'choice' apparently, but simply because there is very little available food there. They do not fast on the bottom where a certain amount of food is available, and they break their fast afterwards in the upper layers when opportunity offers-as it sometimes does in an otherwise barren sea by the appearance of a shoal of small pelagic fish such as Maurolicus pennanti. Amongst samples of mackerel from the Celtic Sea area in early spring, most of which are fasting, it is not unusual to find a few individuals whose stomachs are packed with those small fish, as many as thirteen having been counted in a single stomach.

Of the 753 mackerel caught between 1936 and 1939 on the bottom between Lizard Head and Start Point (p. 528) $67 \%$ contained considerable quantities of food consisting chiefly of small fish and Euphausiids (Nyctiphanes couchii). ${ }^{2}$ On the other hand, 600 pelagic fish caught by drift net in the Celtic Sea in the months of $\mathrm{March}^{3}$ during those years contained food in only $43 \%$ of the stomachs and then only in very small quantities, apart from a few individuals that had gorged themselves with Maurolicus pennanti.

${ }^{1}$ Broken lines indicate movements that are as yet presumed and not proved.

2 One stomach contained seventy-three individuals of this species plus unidentifiable crustacean remains.

${ }^{3}$ No drift net samples were examined in January and February. 
Over the course of one full year, therefore, the life of most adult mackerel in the south-west region appears to fall into two main periods, a demersal period and a pelagic period, with a brief transition period during which the fish return to the bottom and reform shoal. ${ }^{1}$ This can conveniently be summarized as follows:

I. Demersal Period

(i) Compact phase

Intensely dense and extremely circumscribed concentrations of fish massed on the sea floor in very localized positions distributed over wide areas.

(ii) Deployment phase

November, December

Concentration diminishes; still keeping to the bottom the fish spread slowly outwards over adjacent areas before ascending to the upper waters and giving rise to pelagic shoals.

December, January, February

2. Pelagic PERIOD

(iii) Shoaling phase

Active migration of the shoals to the spawning grounds and return (or continuation) shorewards.

(iv) Dispersal phase

January-July

Shoals broken up and fish dispersed in inshore waters around all coasts.

\section{TRANSITION PERIOD}

June-October

(v) Reconcentration phase

Disappearance from surface waters and return to phase (i).

October, November

During phase (ii) - the deployment phase-the fish appear to perform small diurnal vertical movements, rising from the sea floor during the night and descending again during the day. Trawling during this phase is therefore most successful during daylight hours (Bullen, I908, p. 283).

\section{Discussion}

In the light of this new information concerning the habits and migrations of adult mackerel in the south-western region it is instructive now to examine what is known of their movements and behaviour in other places.

1 These changes do not take place everywhere simultaneously, so there is no period of the year during which at least a few scattered schools of pelagic mackerel cannot be found. 
With regard to mackerel in all the European seas Allen (I897, p. 25) makes the general and comprehensive statement that ' the first approach of the mackerel to the coast in spring or early summer is for the purpose of spawning' and adds the interesting comment that 'the advantage to the species of the young fish being hatched out near the shore where the smaller forms of pelagic organisms are present in abundance and the plankton is increased by the numerous larval forms of those species which inhabit coastal waters, is obvious'.

With special reference to the Celtic Sea and the English Channel area Allen (I897, pp. I2, I7) mentions the presence of fish 30-40 miles from land between Start Point and Plymouth in the months of January to March, at the same time giving the end of March or early April as the time of the approach of the main shoals ' towards the southwest coasts of Ireland and the west coast of France'. He makes no attempt to explain the presence of mackerel so far up channel in winter and early spring while the main shoals are still far away to the westward. Ehrenbaum (19I4, p. I3) also states that the great majority of English Channel mackerel appear to arrive in early spring from the adjacent waters of the Atlantic. He attempts to explain the presence of mackerel far up the channel long before the main shoals arrive by suggesting that 'the mackerel sometimes move, in great numbers, still keeping to deep water, far eastward, into the Channel', before rising to the surface. This author, too, believed that mackerel everywhere move in towards the coasts in spring to spawn (19I4, p. I7) and gives the months of May, June and July as 'the true spawning time' in both European and North American waters. Much emphasis is placed upon this uniformity of spawning in such widely distant regions. Only in the Mediterranean is the spawning time stated to be 2 months earlier. In a footnote Ehrenbaum (I9I4, p. 75) makes only passing reference to an important statement by Rathbun, quoting Hardin (I896, p. 8I) who found in the New York market mackerel taken on the 17 April some 65 miles south-east of Cape Henry, that were already spent. This observation is possibly of much more importance than Ehrenbaum attaches to it and may indicate much earlier spawning than has been ascribed to mackerel in those waters (cf. p. 535, infra).

Meek (I9I6, p. 320), also in a general statement embracing all mackerel (Scomber scombrus), says that 'the spawning migration is an anadromous one', that the season is May to July, and that spawning takes place when they arrive in coastal water (op. cit., p. 326).

Although, as we now know, these general statements concerning the mackerel do not hold good in the English Channel and Celtic Sea, it is significant that, in the North Sea, they are partly true. In that area by far the largest number of mackerel eggs have always been found on the Norwegian side of the Skagerrak very close to the south coast of Norway (Ehrenbaum, I9I4, p. I8), and at its inner end off the Swedish coast from Väderöfjord to Hallö and Paternoster 'and thence diagonally across to the Skaw' (Ehrenbaum, I923, p. II). Here, without doubt, is a shoreward migration to spawn, chiefly in 
the months of May, June and July. But it should be noted, by reference to a chart of the eastern North Sea, that although the migration is shoreward from adjacent offshore waters, it is at the same time a migration from shallower water to the vicinity of the I00-fathom contour.

There is thus a very close similarity between what we now know to be the chief spawning locality of the south-western region and that of the North Sea area. Both lie close to the roo-fathom line. In both areas this contour closely follows the edge of a well-marked slope in the sea bed from shallow to deep water-i.e. to the depth of the Atlantic Ocean in the Celtic Sea; and, in the Skagerrak, to the lesser but, nevertheless, considerable depths (over 400 fathoms) that are present there and which are not found anywhere else in all the North Sea region.

There is the further similarity that mackerel eggs are found, but in much smaller numbers, widely distributed over adjacent parts of the North Sea and the Kattegat (Buchanan-Wollaston, I9II, p. 2I8). Ehrenbaum has shown that in the North Sea, too, during the colder season of the year, from November till about May, great numbers of mackerel are present on the bottom chiefly around the Great Fisher Bank and northwards to the Viking Bank along the edge of the Norwegian Channel (I9I2, p. 4; I9I4, p. 36). He also points out that the trawl catches of these fish over the different months of the year 'seem. to indicate that the mackerel taken in winter are for the most part identical with the shoals which in spring appear on the coasts of the North Sea and Skagerrak in order to spawn' (1914, p. 36).

What we now find, therefore, is that after spending the winter months on the sea floor in the vicinity of the slopes produced by banks and gulleys, the mackerel in both the North Sea and south-western areas migrate to certain restricted spawning grounds in the vicinity of the roo-fathom line. It so happens that in the North Sea this contour lies close to the Norwegian and Swedish shores. This brings about the anomalous result that mackerel migrating from the shallow waters of the North Sea to spawn in the deep waters of the Skagerrak, and, to a lesser extent, in other Norwegian Fjords farther north, are, nevertheless, at the same time also migrating shorewards. That is to say, that most of the mackerel in the North Sea, like their brethren in the English Channel and Celtic Sea, migrate from their winter quarters to deep water to spawn; that in the North Sea this deep water happens to lie close in by the shore whereas in the south-western region it lies far out in the Celtic Sea, a long way from the land.

It is this apparent anomaly that hitherto has led to such confusion in trying to interpret the migrations of the mackerel. The coincidence that the deep water they favour happens, in the North Sea, to lie hard by the land, and that this was the first spawning ground to be investigated has given rise to the belief that all mackerel migrate shorewards to spawn. The fact that mackerel eggs are never found except in comparatively small numbers near the shore around 
the south and west coasts of England should have led to at least a suspicion that this did not hold good there. But with only one remarkable exception this suspicion seems never to have arisen in anyone's mind. The exception was a very enlightened fisherman, Matthias Dunn of Mevagissey, Cornwall, who, in 1893 (p. 3), stated quite definitely that the spawning grounds of the mackerel in the south-west region 'are in those waters covering the plateau of ground within the two-hundred-mile limit of our western and south-western shores, known to our sailors as about or within soundings'. This remarkably accurate statement is not even mentioned, so far as I can ascertain, by any subsequent investigators. Perhaps they had never come across it; or perhaps (more likely) they considered it to be too preposterous for serious consideration. Day (1880-84, p. 85), however, appears to have retained an open mind on the subject, for he says that at certain seasons mackerel approach the shores in countless multitudes 'either prior to, during, or after breeding'.

Respecting the migrations of the mackerel on the western side of the North Atlantic there existed for a long time two very well-defined schools of thought. One held that the mackerel undertook extended migrations both to and from deep water well offshore, and also along the shore, when this was reached, in a south to north direction (Brown Goode, 1879, p. 63). Other investigators and observers (quoted by Brown Goode, I879, pp. 56 et seq.) ${ }^{1}$ held that the mackerel spent the winter on the sea floor, not very far from their summer haunts, where they lay in a comatose state either on or even partly embedded in the bottom mud or sand. These apparently opposing views were, in fact, held by American and Canadian workers respectively and were fiercely debated in a controversy concerning American rights to fish in Canadian waters. The American argument was that, since the shoals moved northward from American to Canadian waters, American fishermen were entitled to follow them thither. The Canadians held that, on the contrary, such migrations did not take place and opposed the American claim to a right to fish in their waters.

Each side provided some useful evidence in support of its claim. The American view was supported by the northward movement of the fishery. Canada depended mainly on rather fanciful 'eye-witness accounts' of mackerel being seen on the bottom in a torpid state in winter months, and on the more reliable fact that mackerel occasionally could be caught by nets on the bottom near the shore in winter. Brown Goode himself (1884, p. I02) more or less admits the claim that mackerel are not infrequently found in the stomachs of cod and halibut taken on and near the bottom on George's Banks in the winter season, and Collins (I883, p. 274) reported that in late February, I882, many mackerel were taken in the stomachs of cod that had been caught near bottom some Io miles off Egg Harbour, N.J., in I2-I5 fathoms of water. Summing

1 The very early Canadian publications by W. F. Whitcher and Henry Youle Hind have not been available to me for direct consultation. 
up, Brown Goode conceded rather grudgingly that 'it is by no means demonstrated that certain schools of mackerel do not remain throughout the year in waters adjacent to the coasts of Canada' (I884, p. 96). Nevertheless, he considered such cases to be quite exceptional and held firmly to the conviction that the weight of available evidence was overwhelmingly in favour of those who held that the mackerel make extensive migrations along the coasts, in addition to returning to deeper parts of the ocean on the approach of winter.

As more information became available, however, the views of both parties became so modified that Bigelow (I925, p. I92) was able to state that "scientific opinion has gradually crystallized to the effect that the essential features of the seasonal migrations of the mackerel are essentially a spawning journey inshore and into shallow water in spring alternating with an offshore movement combined with a descent into deep water in autumn'. He then adds that, according to geographic conditions, these 'fundamental changes of situation' are accompanied by horizontal journeys of greater or less length and in various directions. According to this author (I925, p. 206) mackerel spawn off the North American coast from the latitude of Cape Hatteras ( $35^{\circ}$ I $5^{\prime}$ N.) to the Gulf of St Lawrence, where the heaviest spawning along the whole coastline takes place, closely followed by the Gulf of Maine, especially in the Massachusetts Bay area. In the latter region the chief spawning season is said to extend over the last half of May and the month of June; in the Gulf of St Lawrence spawning activity reaches its maximum a month later in the latter half of June and the first two weeks of July.

Although exact comparisons are impossible because of the different methods and gear used for collection, it may be significant that the records of mackerel eggs obtained in both those regions (Bigelow, I925, p. 206; Dannevig, I9I8, p. 8; Sparks, I929, pp. 445-450) reveal widespread distribution of eggs in comparatively shallow coastwise waters in numbers that appear to be comparable with those obtained by Corbin in the Celtic Sea to landward of the main spawning centres after maximum spawning intensity had passed. If this indeed be so, much importance must be attached to Bigelow's further statement (I925, p. 207) that, in the Gulf of Maine region, egg records from offshore localities, though extremely scanty, nevertheless clearly indicate that spawning takes place in the vicinity of some or all of the many banks that lie well offshore and over deep water ${ }^{1}$ as well as in the shallow coastwise waters of the inner parts of the Gulf.

The evidence so far available, therefore, appears to point very strongly to the probability that the habits and migrations of the mackerel on the western side of the North Atlantic will, on further investigation, be found to be very

1 Bigelow appears here to be referring to depths of less than about 180 fathoms, the deepest soundings found in the various deeps and basins of the Gulf of Maine which is the oceanic bight between Cape Cod and Cape Sable. He adds (I925, p. 209) that 'there is no reason to suppose that they ever breed outside the continental slope', the edge of which, in that region, follows more or less closely the 200 -fathom contour. 
similar to those of their European kin around the south-west of England and in the North Sea. The existence of hitherto undiscovered, restricted spawning centres of high spawning intensity, probably in the vicinity of the I00-fathom line perhaps as early as April in both the Gulf of Maine and the Gulf of St Lawrence, seems highly probable; and examination of the charts of the two regions suggests that they are well suited to the needs of the mackerel as revealed by our recent researches in the English Channel and Celtic Sea.

Although the migrations of the adult mackerel in the English Channel and Celtic Sea have now become clear, the migrations of the young and immature fish are still obscure, but mention must be made of what little we do know concerning them. Corbin (1947, pp. 73-76) has shown that the larval and postlarval stages, as would be expected, are numerous on the spawning grounds for a short time after the eggs have hatched out; thereafter, they disappear from catches and little is known concerning them. During our investigations the largest postlarva captured in these waters was $21 \mathrm{~mm}$. in length caught in the month of June.

But small mackerel, of from about 13 to about $17 \mathrm{~cm}$. in length, appear in some years in bays, harbours, and estuaries around the south-western shores of England for a short period in early autumn. In I 926 small fish appeared in Plymouth Sound in August and several were caught in sprat nets, their size ranging from 13.0 to $17.2 \mathrm{~cm}$. in length (mean length of all fish $15.3 \mathrm{~cm}$.). In 1927 small mackerel again appeared in the bays and estuaries around the Devon and Cornwall coasts. Fifty of them caught in a sprat seine during August had a mean length of $13.6 \mathrm{~cm}$., the total range being $12.5-15.2 \mathrm{~cm}$. In 1937, 273 small mackerel caught at Newlyn on 4, 6, and 7 August had a length range of $8 \cdot 0-16.4 \mathrm{~cm}$. with a mean length of $12.7 \mathrm{~cm}$. Those fish first appeared in the middle of July and remained inshore until nearly the end of September. They were present in very large numbers-so much so that reports of their presence in such abundance were at first disbelieved. Many Newlyn fishermen were very definite in their assertions that they had never seen mackerel of such small size before.

Their appearance, in fact, in inshore waters in this region, takes place only at long and irregular intervals. Nor are they found with any greater frequency elsewhere in British waters. The Scottish Fishery Board ${ }^{1}$ records the capture of small mackerel on the bottom in a small-meshed covering of the cod end of an otter trawl in September and November 1929; September and October 1930; September and October 1932; August, September and October 1933; August 1935; and in September 1936.

There are no records in the Board's log-books of any catches of these small sizes in $1927,1928,1931,1934$ and 1937.

The capture of small mackerel is not to be expected in an uncovered trawl, but Hickling, ${ }^{1}$ while fishing for hake off the west coast of Ireland, has come across them in the stomachs of hake and certain other fishes. Ehrenbaum

\footnotetext{
1 Private communication.
} 
(I923, pp. I9 et seq.) gives details of the capture of small mackerel in the North Sea by several workers of different nationalities in the late summer and autumn. Malm (I877, p. 409) mentions a great shoal of small mackerel that appeared in the Skagerrak, near Christenburg in the Gullmarfjord, on 27 July I872. They were so small that they all escaped through the meshes of ordinary seines and only ten could be obtained for examination. These fish were between 67 and $100 \mathrm{~mm}$. in length. To the fishermen of the district such small mackerel had until then been entirely unknown so that, as on the Channel coast of England, they must arrive only on rare occasions at long intervals.

From the information available, therefore, meagre and incomplete though it be, it is evident that juvenile mackerel, like the adults, are present at times on the sea floor and at other times in the upper layers of the sea. Their appearance in some years in huge numbers in inshore waters for a few weeks in summer and early autumn reveals that they also carry out migrations, but the fact that they do not appear around the shores every year suggests that those migrations, in the main, are less extensive and less regular than those of the adult fish.

One cannot but conclude, therefore, that the migratory behaviour of young mackerel may be very similar to that of the adults; that they seek bottom in the late autumn and winter and rise again to the upper layers in due season. As they so seldom come inshore, it would appear that their horizontal migrations are, as a rule, less extensive than those of adult fish. As they grow and approach maturity, those migrations must approximate more and more closely to those of the adults until at last, when they reach maturity, they join the spawning shoals and migrate with them.

\section{SUMMARY}

In the English Channel and Celtic Sea mackerel spend the winter months on the sea floor densely packed in places where its level is interrupted by banks and gulleys.

In the early spring the fish rise to the surface and migrate to a common spawning ground that lies far out to the westward of the Scilly Islands in the vicinity of the Ioo-fathom contour.

The very localized positions in which mackerel spend the winter are widely distributed throughout the area in both deep and shallow water. Large schools of migrating fish converge upon the spawning ground from many directions, therefore, in the spring for spawning.

Fish that have wintered near the land must migrate offshore to reach the spawning ground; those that spend the winter on the bottom to seaward of the spawning ground must migrate shorewards to reach it. Off the south-west of England there is no single shoreward migration to spawn in shallow water as has previously been thought.

In the North Sea the chief spawning grounds of the mackerel are also near the IOO-fathom contour which, in that region, happens to lie very close to the land 
in the Skagerrak and along the Norwegian coast. The chief spawning migration of the North Sea mackerel is therefore towards the coast from offshore localities. This migration is, at the same time, chiefly from shallow to deeper water.

Existing information concerning the mackerel populations on the western side of the North Atlantic points to the probability that their spawning habits and migratory movements do not differ greatly from those of the mackerel in North European waters.

\section{REFERENCES}

ALLEN, E. J., I897. Report on the present state of knowledge with regard to the habits and migrations of the mackerel (Scomber scomber). Fourn. Mar. Biol. Assoc., Vol. v, pp. I-40.

Bigelow, Henry B., 1925. Fishes of the Gulf of Maine. Bulletin of the United States Bureau of Fisheries, Vol. XL, for I924, Pt. I, pp. I-567. [Section on mackerel, pp. I88-208.]

Brown Goode, G., I879. A history of the menhadan. U.S. Comm. of Fish and Fisheries: Commissioner's Report for 1877 (1879), pp. I-529. [Section on mackerel migrations, pp. 50-7I.]

- I884. Materials for a history of the mackerel fishery. I. Natural history. U.S. Comm. of Fish and Fisheries: Commissioner's Report for I88I (1884), pp. 9I-I38.

BuchanaN-Wollaston, H. J., I9I I. Report on the results of the fish-egg cruise made by the S.S. Huxley in June, I909. North Sea Investigations Committee; Fishery and Hydrographical Investigations in the North Sea and Adjacent Waters, pp. 20734. London.

BULleN, G. E., I908. Plankton studies in relation to the western mackerel fishery. Fourn. Mar. Biol. Assoc., Vol. viII, pp. 269-302.

CALDERWOOD, W. L., I892. Monthly reports on the fishing in the neighbourhood of Plymouth. Fourn. Mar. Biol. Assoc., Vol. II, pp. 277-79.

I892. Monthly reports on the fishing in the neighbourhood of Plymouth. II. fourn. Mar. Biol. Assoc., Vol. II, pp. 394-95.

I I893. Monthly reports on the fishing in the neighbourhood of Plymouth. III. Fourn. Mar. Biol. Assoc., Vol. III, pp. I07-IO.

Cligny, A., 1905. Les prétendues migrations du maquereau. Ann. Sta. Aquicole, Boulogne-sur-Mer, N.S., T. I, pp. 97-100.

- Le stationnement du hareng et du maquereau sur le fond avant la ponte et son importance pour la pêche au chalut. Ann. Sta. Aquicole, Boulogne-sur-Mer, N.S., T. II, pp. I2I-48.

ColliNs, J. W., I883. Notes on the movements, habits, and capture of mackerel for the season I882. Bull. U.S. Fish Commission, Vol. II, pp. 273-85.

Corbin, P. G., I947. The spawning of the mackerel Scomber scombrus L., and pilchard Clupea pilchardus Walbaum, in the Celtic Sea in 1937-39, with observations on the zooplankton indicator species Sagitta and Muggiaea. Fourn. Mar. Biol. Assoc., Vol. xxvII, pp. 65-I32.

CUNNINGHAM, J. T., I889. Studies of the reproduction and development of teleostean fishes occurring in the neighbourhood of Plymouth. Fourn. Mar. Biol. Assoc., Vol. I, pp. 10-54.

Dannevig, Alf., I9I8. Canadian fish eggs and larvae. Can. Fish. Expdn. I9I4-15, Dept. Nav. Service, Ottawa, I918, pp. I-74.

Day, Francis, I880-84. British Fishes. [Vol. I, pp. 83-9I and plates XXXII and XXXIII.] 
Dunn, Matthias, I893. The mackerel. Rep. Cornwall Polytechnic Soc., pp. I-I5.

Ehrenbaum, E., I912. Report on the mackerel. Preliminary account. Cons. Perm. Int. Expl. Mer: Rapp. Proc.-verb., Vol. xIv, pp. I-IO.

- I I I4. The mackerel and the mackerel fishery. Cons. Perm. Int. Expl. Mer: Rapp. Proc.-verb., Vol. xviII, Special Report, pp. I-IoI.

- I923. The mackerel. Spawning-larval and postlarval forms-age groupsfood-enemies. Cons. Perm. Int. Expl. Mer: Rapp. Proc.-verb., Vol. xxx, pp. I-39.

GreEN, W. S., I894. Notes on the Irish mackerel fisheries. Bull. U.S. Fish Commission, Vol. xIII, pp. 357-60.

${ }^{1}$ HIND, HENRY YoulE, I877. The effect of the fishery clauses of the treaty of Washington on the fisheries and fishermen of British North America. Fishery Commission, Halifax, I877, pt. II.

Le Gall, J., I928. Notes sur le maquereau. Revue des Travaux de l'Office des Pêches Maritimes. T. I, Fasc. I, p. 54.

- 1935. La pêche du maquereau. Man. des pêches maritimes françaises. Mémoires de l'Office des Pêches Maritimes (Série spéciale), No. Io, Fasc. 2, pp. 78-92.

MALM, A. W., I877. Göteborgs och Bohusläns Fauna, pp. 408-I2.

MeEk, A., I9I6. The Migrations of Fish. London: Edward Arnold. [Chapter xxiv, pp. 319-30; mackerels and tunnies.]

Ministry of Agriculture AND Fisheries. Sea Fisheries Statistical Tables for the Years 1906-1938 inclusive. [N.B. Until 1918 the tables were included in the Annual Report on Sea Fisheries. From I9I9 onwards the tables have been published separately.]

RATHBUN, RICHARD, I896. Report upon the inquiry respecting food-fishes and the fishing-grounds. U.S. Comm. of Fish and Fisheries. Commissioner's Report for I895 (I896), pp. 73-92.

RIDGe, R. J., I889. The mackerel fishery in the west of England. Fourn. Mar. Biol. Assoc., Vol. I, pp. 72-73.

ScotT, A., I9I3. On the pelagic fish eggs collected off the south-west of the Isle of Man. Rep. Lancs. Sea-Fish. Labs., No. xxI, pp. 233-53.

- I9I4a. The mackerel fishery off Walney in I913. Rep. Lancs. Sea-Fish. Labs., No. xxII, pp. I9-25.

- I9I4b. On the pelagic eggs collected in I9I3. Rep. Lancs. Sea-Fish. Labs., No. XXII, pp. 26-36.

SPARKS, M. I., I929. The spawning and development of mackerel on the outer coast of Nova Scotia. Contr. Canadian Biol. and Fisheries, N.S., Vol. Iv, No. 28, pp. 445-52.

Steven, G. A. \& Corbin, P. G., I939. Mackerel investigation at Plymouth. Preliminary report. Cons. Perm. Int. Expl. Mer: Rapp. Proc.-verb., Vol. cxi, Appendice 2, pp. 15-18.

ThOMpson, D'ARCY Wentworth (Editor), I939. Bulletin Statistique des pêches maritimes, Vol. xxvir, pour l'année I937.

${ }^{1}$ WHITCHER, W. F., American theory regarding the migration of the mackerel refuted. Rep. of the Minister of Marine and Fisheries of the Dominion of Canada for the year ending 30 th Fune, 1871 .

1__ On the supposed migration of the mackerel. Rep. of the Minister of Marine and Fisheries of the Dominion of Canada for the year ending 3oth Fune, 1872.

1 See footnote, p. 534. 